\title{
AN ANALYSIS OF CONSUMER PREFERENCES FOR BED AND BREAKFAST IN THE ECO-AGRITOURISM ACTIVITIES
}

\author{
S. Arumugam ${ }^{* 1}$, R. Govindasamy ${ }^{2}$ and I. Vellangany ${ }^{3}$ \\ ${ }^{1}$ Post-Doctoral Fellow, Department of Agricultural, Food and Resource Economics, Rutgers- \\ The State University of New Jersey, New Brunswick, NJ, USA \\ ${ }^{2}$ Professor and Chair, Department of Agricultural, Food and Resource Economics, Associate \\ Director, New Use Agriculture and Natural Plant Products, Extension Specialist, Rutgers \\ Cooperative Extension, Rutgers-The State University of New Jersey \\ New Brunswick, NJ, USA \\ ${ }^{3}$ Assistant Professor, Department of Agricultural, Food and Resource Economics, Rutgers- \\ The State University of New Jersey, New Brunswick, NJ, USA
}

\begin{abstract}
This study evaluatesthe socio-economic demographic, as well as the preferences and behavioral characteristics of consumers who participate in bed and breakfast agritourism activity. The results from the logit model indicate that those who consumed a wider variety of fruits in the past 5 years, those who learn about agritourism from sign at market, those who consider that the facility at agritourism sites are important, those who have children under the age of 17 , those who are retired from the job, and whose income range between $\$ 60,000$ to $\$ 79,000$ are more likely to be willing to participate in the bed and breakfast agritourism activity. However, those who learn about agritourism from newspapers, those who have two year collage education, male, homemakers, and whose income range from $\$ 20,000$ to $\$ 39,000$ are less likely to be participate in bed and breakfast agritourism activity in Mid-Atlantic Region.
\end{abstract}

Keywords: Agritourism, willing to participate, bed and breakfast, logit model, mid-atlantic region

\section{INTRODUCTION}

Land use activities, for example transforming natural environment for human use or altering management practices on lands, have converted a large portion of the planet as a developed land surface (DeFries et al., 2004; Foley et al., 2005; Sutherland et al., 2016). One of the consequences of this transformation is the disappearance of farmland in favor of 'urban sprawl', especially in the North Eastern

\footnotetext{
* Corresponding author email: arumugam@aesop.rutgers.edu
} 
United States. Corollary to this transformation is the emergence of two types of farm holdings: farms with less than 50 acres and farms with more than 500 acres have both of which have increased their share of total farm holdings since 1974, with a decline in the midsize farms (USDA, 2012). Small farms, mainly family owned, still hold the 'mythic standing' in the United States, harking back to the 'Jeffersonian romantic sensitivities' (Browne, 2001; Lipton, 2005; Schilling, 2014; Onyango et al., 2015). Protecting small farms has long been a federal and State policy objective, rationalized in part by the priority of maintaining local food production, and safeguarding the environment and reflection of the inherent value Americans place on the rural landscape. The local economy has a direct impact on the prosperity of these family farms through the availability of off-farm jobs and the success of nonfarm businesses owned by farm operators and their family members. On an average 91 percent of U.S. farms are classified as small farm with a gross cash farm income (GCFI) of less than $\$ 250,000$. About 60 percent of these small farms are very small, generating GCFI of less than $\$ 10,000$ (USDA, 2010). The sustainability and the long term viability of these farms are at stake, unless farmers adapt by finding new market niches in alternate income generating activities.

Tourism is one of the fastest and leading industries in the world (Edgell, 1990; WTO, 2004; Kumar et al, 2016). In both developed and developing countries, tourism, eco-tourism and agritourism are frequently considered to be a sustainable way of raising the economic activity of regions (Ceballos, 1995, Surendran and Sekar, 2010; Tew and Barbieri, 2012; Koutsouris et al., 2014; Chiu et al., 2016). A recent trend in this regard is the utilization of natural resources for tourismto diversify income, and to reduce risks that are an inherent nature of agriculture, ecosystem services, and biodiversity (Nickerson et al., 2001; McGehee and Kim, 2004; Che et al., 2005; Surendran and Sekar, 2011; Tew and Barbieri, 2012; Barbieri, 2013). Agritourism is defined "as embracing the full range of products and services, development options and marketable linkages possible across the AgriFood-Tourism value chain, including those tourism products developed for rural/urban/agricultural environments" (Harvey, 2001). University of California Small Farm program (2012) define it as "Agricultural tourism is a profitable venture at a working farm, ranch or agricultural plant conducted for the enjoyment or education of visitors, and that generates additional income for the farmers". Agritourism can include U-pick, farm stays, farm stand or shops, tours, on-farm classes, orchard dinners, fairs, festivals, Christmas tree farms, pumpkin patches, winery weddings, youth camps, hunting or fishing, barn dances, guest ranches, and more'.

U. S. Department of Agriculture assessed that more than 62 million Americans, who were at least 16 years of age or older, and 20 million children, under the age of 16, visited agricultural farm (NSRE 2002; Wilson, Thilmany and Sullins 2006; Onyango et al., 2015).Their genuine interest in agritourism and supporting direct marketing also fuels travel and tourism. It is clear that the desire for tourism, 
along with the value and quality of goods and services, will continue to attract consumers in the future, assuming that demand will continue to be met by farm operators. The purpose of this study is to elucidate consumers' perception to participating in bed and breakfast agritourism activity and attributes that influence their decision to undertake such agritourism activities. Factors that derive demand for agritourism businesses and determine who will visit are imperative to know in order to further develop plans on an individual level. Since, agritourism activities are key regional business development strategies, all information that comes directly from consumers could motivate owners to plan, act, and improve their businesses in accordance with the findings.

\section{METHODOLOGY}

An online survey of consumers living in New Jersey, Pennsylvania, and Delaware was conducted in 2010 to document the characteristics of consumers who visit agritourism operations and/or buy at farmer-to-consumer direct market outlets in the northeastern United States. Among the 2594 members who were registered with this panel and accessed the survey, 1134 met the screener criteria and began the survey (133 from DE, 424 from NJ, and 577 from PA), with 993 completing the 15minute survey questionnaire (364 from NJ, 507 from PA and 122 from DE). Panelists were enquired to quantify the amount of produce procured at direct marketing outlets, the number of visits per month, the type of produce bought and dollars spent during per visit at the farmer-to-consumer direct market outlets, as well as demographic questions (e.g., gender; age; household size; annual gross household income etc.).

\section{MODEL SPECIFICATION}

The respondents were interviewed whether they are willing to participate in a bed and breakfast event in the agritourism activity. In the logit model framework, the dependent variable is defined as ' 1 'if the respondent is willing to participate in a bed and breakfast agritourism activity and ' 0 ' otherwise. The empirical model assumes that the probability of observing the dependent variable $P_{i}$ is contingent upon the vector of independent variables Xij associated with visitor (i) and variable (j). The relationship between willingness to participate in a bed and breakfast agritourism activity, visitor's behaviors, agritourism attributes, and socio-demographic characteristics were explored as follows:

$$
\begin{aligned}
P_{i}=F\left(\beta_{j} \chi_{i j}+\right. & \varepsilon) \ldots \ldots \ldots \ldots \ldots \ldots \ldots \ldots \ldots \ldots \ldots \ldots \ldots \ldots \ldots \ldots \ldots \ldots \ldots \ldots \ldots \ldots \ldots \ldots \ldots \ldots \ldots \\
& =\beta_{0}+\beta_{1} \text { Visitor's Behavior }+\beta_{2} \text { Agri }- \text { tourism Attributes } \\
& +\beta_{3} \text { Socio }- \text { Demographic Characteristics }+\varepsilon
\end{aligned}
$$

Where:

$P_{i}$ is the probability of willing to participate in the bed and breakfast event, 
$\beta_{j} \chi_{i j}$ is the linear combination of independent variable.

$\beta$ is the parameters to be estimated. $-\varepsilon$ is adisturbance term orerror term.

Logistic distributional assumption for the random term, the probability $P_{i}$ can be expressed as:

$$
P_{i}=F\left(\beta_{0}+\sum_{j=1}^{j} \beta_{j} \chi_{i j}\right)=F\left(\beta \chi_{i}\right)=1 /\left[1+\exp \left(-\beta \chi_{\mathrm{i}}\right)\right]
$$

The estimated coefficients in Equation 2 do not directly represent the marginal effects of the independent variables on the probability $P_{i}$.

If the dependent variable is continuous, the marginal effect of $\chi_{i}$ on $P_{i}$ is given as:

$$
\partial P_{i} / \partial \chi_{i j}=\left[\beta_{j} \exp \left(-\beta \chi_{i}\right)\right] /\left[1+\exp \left(-\beta \chi_{i}\right)\right]^{2}
$$

In the case of a binary explanatory variable $\chi_{i j}$ which take values of 1 and 0 , and the marginal effect is determined as:

$$
\partial P_{i} / \partial \chi_{i j}=\left[P\left(\chi_{i j}=1\right)-P\left(\chi_{i j}=0\right)\right] /[1-0] \text {. }
$$

The logit model is formulated as:

BBFAST $==\beta_{0}+\beta_{1}$ MOREFRUITS $+\beta_{2}$ WIDERFRUITS $+\beta_{3}$ PYOVISITS $+\beta_{4}$ PYOEXP

$+\beta_{5}$ AGRITOURVISITS $+\beta_{6}$ DMBILLBOARDADV $+\beta_{7}$ DMATMARKETADV

$+\beta_{8}$ WTPDIRECTMKT $+\beta_{9}$ WTBGM $+\beta_{10}$ AGRITOURMKT

$+\beta_{11}$ AGRITOURPAPER $+\beta_{12}$ FACILITYIMP $+\beta_{13}$ EDUCATIONIMP

$+\beta_{14}$ GARDEN $+\beta_{15}$ URBAN $+\beta_{16}$ HOUSEHOLD $+\beta_{17}$ UNDER17

$+\beta_{18}$ MALE $+\beta_{19}$ AGE $<20+\beta_{20}$ AGE21TO35 $+\beta_{21}$ AGE36TO50

$+\beta_{22}$ YYEARCOLLGE $+\beta_{23}$ 4YEARCOLLEGE $+\beta_{24}$ GRADUATE

$+\beta_{25}$ RETIRED $+\beta_{26}$ EMPLOYED $+\beta_{27}$ HOMEMAKER $+\beta_{28}$ STUDENT

$+\beta_{29}$ CAUCASIAN $+\beta_{30}$ INC20K-39K $+\beta_{31}$ INC40K-59K $+\beta_{32}$ INC60K-79K $+\beta_{33}$

INC80K-99K $+\beta_{34}$ INCABOVE100K.

The dependent variable is dichotomous such that it equals' 1 ' if the respondent participated in bed and breakfast agritourism activities; $0=$ otherwise. Independent variables include participant's attitudes, behaviors and socio-economics characteristics.

\section{RESULT AND DISCUSSION}

Survey participants were selected randomly from direct marketing and agritourism consumers in the Mid-Atlantic region, specifically in the states of New Jersey, Delaware, and Pennsylvania. The independent variables were used in the logit model to predict the factors that influence the respondent's willingness to participate 
in bed and breakfast agritourism activity. In table 1, the discrete and continuous independent variables are explained in terms of average units and the binary dummy variables are explained in terms of percentage distribution. For example, On an average, $17 \%$ of respondent participated in bed and breakfast agritourism activity (BBFAST) and the remaining 63\% of them were not. The average number of visits per year to a Pick-Your-Own operation was about 1.97 times (PYOVISITS) and per visit they spent about $\$ 13.51$ (PYOEXP) etc,. Hence, none of the hypothesis was made towards behavioral and perceptional attitudes of participants.

Table 1. Description of independent variables

\begin{tabular}{|c|c|c|c|c|}
\hline S. No & Variable & Description & $\begin{array}{c}\text { Mean } \\
\text { Units/ } \\
\%\end{array}$ & $\begin{array}{c}\text { SD } \\
\text { Units/ } \\
\%\end{array}$ \\
\hline & BBFAST & $\begin{array}{l}1 \text { if participant participated in bed and } \\
\text { breakfast agritourism activity; } 0=\text { otherwise }\end{array}$ & 0.17 & 0.37 \\
\hline 1. & MOREFRUITS & $\begin{array}{l}1 \text { if the participant consumed more fruits in } \\
\text { the past } 5 \text { years; } 0=\text { otherwise }\end{array}$ & 0.73 & 0.44 \\
\hline 2. & WIDERFRUITS+ & $\begin{array}{l}1 \text { if the participant consumed a wider } \\
\text { variety of fruits in the past } 5 \text { years; } \\
0=\text { otherwise }\end{array}$ & 0.85 & 0.36 \\
\hline 3. & PYOVISITS & $\begin{array}{l}\text { Average number of visits per year to a } \\
\text { Pick-Your-Own operation }\end{array}$ & 1.97 & 2.79 \\
\hline 4. & PYOEXP & $\begin{array}{l}\text { Average amount spent per visit at a Pick- } \\
\text { Your-Own operation }\end{array}$ & 13.51 & 13.05 \\
\hline 5. & AGRITOURVISITS & $\begin{array}{l}\text { Average number of visits per year to an } \\
\text { agritourism location }\end{array}$ & 2.96 & 2.43 \\
\hline 6. & DMBILLBOARDADV & $\begin{array}{l}1 \text { if the participant learns about direct } \\
\text { markets through billboard and roadside } \\
\text { sign advertisements; } 0=\text { otherwise }\end{array}$ & 0.39 & 0.49 \\
\hline 7. & DMATMARKETADV & $\begin{array}{l}1 \text { if the participant learns about direct } \\
\text { marketing outlets from sign at the market } \\
\text { entrance; } 0=\text { otherwise }\end{array}$ & 0.51 & 0.50 \\
\hline 8. & WTPDIRECTMKT & $\begin{array}{l}1 \text { if the participant is willing to pay more } \\
\text { for agricultural products from direct } \\
\text { markets compared to supermarkets; } \\
0=\text { otherwise }\end{array}$ & 0.64 & 0.48 \\
\hline 9. & WTBGM & $\begin{array}{l}1 \text { if the participant is willing to buy } \\
\text { genetically modified products; } 0=\text { otherwise }\end{array}$ & 0.17 & 0.37 \\
\hline 10. & AGRITOURMKT+ & $\begin{array}{l}1 \text { if the participant learns about agritourism } \\
\text { from sign at market; } 0=\text { otherwise }\end{array}$ & 0.37 & 0.48 \\
\hline
\end{tabular}




\begin{tabular}{|c|c|c|c|c|}
\hline S. No & Variable & Description & $\begin{array}{c}\text { Mean } \\
\text { Units/ } \\
\%\end{array}$ & $\begin{array}{c}\text { SD } \\
\text { Units/ } \\
\%\end{array}$ \\
\hline 11. & AGRITOURPAPER- & $\begin{array}{l}1 \text { if the participant learns about agritourism } \\
\text { from newspaper; } 0=\text { otherwise }\end{array}$ & 0.53 & 0.50 \\
\hline 12. & FACILITYIMP+ & $\begin{array}{l}1 \text { if the participant thinks that the facility at } \\
\text { agritourism site is important; } 0=\text { otherwise }\end{array}$ & 0.70 & 0.46 \\
\hline 13. & EDUCATIONIMP & $\begin{array}{l}1 \text { if the participant thinks that educational } \\
\text { demonstration and workshops at } \\
\text { agritourism site is important; } 0=\text { otherwise }\end{array}$ & 0.38 & 0.48 \\
\hline 14. & GARDEN & $\begin{array}{l}1 \text { if the participant has a vegetable garden } \\
\text { at home; } 0=\text { otherwise }\end{array}$ & 0.47 & 0.50 \\
\hline 15. & URBAN & $\begin{array}{l}1 \text { if the participant lives in an urban } \\
\text { location; } 0=\text { otherwise }\end{array}$ & 0.11 & 0.31 \\
\hline 16. & HOUSEHOLD & Number of people in the household & 2.89 & 1.40 \\
\hline 17. & UNDER17- & $\begin{array}{l}\text { Number of children below } 17 \text { years in the } \\
\text { household }\end{array}$ & 1.72 & 1.09 \\
\hline 18. & MALE- & 1 if the participant is a male; $0=$ otherwise & 0.25 & 0.43 \\
\hline 19. & $\mathrm{AGE}<20$ & $\begin{array}{l}1 \text { if the participant is less than } 20 \text { years old; } \\
0=\text { otherwise }\end{array}$ & 0.02 & 0.15 \\
\hline 20. & AGE21TO35 & $\begin{array}{l}1 \text { if the participant is between } 21 \text { and } 35 \\
\text { years old; } 0=\text { otherwise }\end{array}$ & 0.29 & 0.46 \\
\hline 21. & AGE36TO50 & $\begin{array}{l}1 \text { if the participant is between } 36 \text { and } 50 \\
\text { years old; } 0=\text { otherwise }\end{array}$ & 0.29 & 0.45 \\
\hline 22. & 2YEARCOLLGE- & $\begin{array}{l}1 \text { if the participant has a two-year college } \\
\text { education: } 0=\text { otherwise }\end{array}$ & 0.27 & 0.44 \\
\hline 23. & 4YEARCOLLEGE & $\begin{array}{l}1 \text { if the participant has a four-year college } \\
\text { education: } 0=\text { otherwise }\end{array}$ & 0.29 & 0.45 \\
\hline 24. & GRADUATE & $\begin{array}{l}1 \text { if the participant has a graduate degree: } \\
0=\text { otherwise }\end{array}$ & 0.16 & 0.36 \\
\hline 25. & RETIRED+ & 1 if the participant is retired; $0=$ otherwise & 0.14 & 0.35 \\
\hline 26. & EMPLOYED & $\begin{array}{l}1 \text { if the participant is employed by others; } \\
0=\text { otherwise }\end{array}$ & 0.54 & 0.50 \\
\hline 27. & HOMEMAKER- & $\begin{array}{l}1 \text { if the participant is a homemaker; } \\
0=\text { otherwise }\end{array}$ & 0.17 & 0.38 \\
\hline 28. & STUDENT & $\begin{array}{l}1 \text { if the participant has up to high school } \\
\text { education: } 0=\text { otherwise }\end{array}$ & 0.07 & 0.25 \\
\hline
\end{tabular}




\begin{tabular}{|c|c|c|c|c|}
\hline S. No & Variable & Description & $\begin{array}{c}\text { Mean } \\
\text { Units/ } \\
\%\end{array}$ & $\begin{array}{c}\text { SD } \\
\text { Units/ } \\
\%\end{array}$ \\
\hline 29. & CAUCASIAN & 1 if the participants Caucasian: $0=$ otherwise & 0.88 & 0.32 \\
\hline 30. & INC20K-39K- & $\begin{array}{l}1 \text { if the participant's income is between } \\
20,000 \text { and } 39,999 ; 0=\text { otherwise }\end{array}$ & 0.19 & 0.39 \\
\hline 31. & INC40K-59K & $\begin{array}{l}1 \text { if the participant's income is between } \\
24,000 \text { and } 59,999 ; 0=\text { otherwise }\end{array}$ & 0.22 & 0.41 \\
\hline 32. & INC60K-79K+ & $\begin{array}{l}1 \text { if the participant's income is between } \\
60,000 \text { and } 79,999 ; 0=\text { otherwise }\end{array}$ & 0.19 & 0.39 \\
\hline 33. & INC80K-99K & $\begin{array}{l}1 \text { if the participant's income is between } \\
80,000 \text { and } 99,999 ; 0=\text { otherwise }\end{array}$ & 0.13 & 0.34 \\
\hline 34. & INCABOVE100K & $\begin{array}{l}1 \text { if the participant's income is above } \\
100,000 ; 0=\text { otherwise }\end{array}$ & 0.19 & 0.39 \\
\hline
\end{tabular}

Results from the logit model confirm the factors that influence respondents' willingness to participate in the bed and breakfast agritourism activity. The chisquare statistics rejected the null hypothesis that the explanatory variables as a set were not important in explaining variations in the dependent variable at 0.001 level and the McFadden's $\mathrm{R}^{2}$ was 0.06265 .The $\chi^{2}$ value was 64.22 with 34 degrees of freedom. The tabulation of prediction success is shown in the classification table (Table 2).

Table 2. Logit model predictive accuracy

\begin{tabular}{c|c|c|c}
\hline \multirow{2}{*}{ Actual Value } & \multicolumn{2}{|c|}{ Predicted } & \multirow{2}{*}{$\begin{array}{c}\text { Correct } \\
\text { Total }\end{array}$} \\
\cline { 2 - 3 } 0 & 0 & 1 & $944(83 \%)$ \\
1 & $940(83 \%)$ & $4(0.4 \%)$ & $190(17 \%)$ \\
Total & $182(28 \%)$ & $8(0.7 \%)$ & $1134(100.00 \%)$ \\
\hline
\end{tabular}

Number of correct predictions: 948 ,

Percentage of correct predictions: $83.6 \%$

McFadden $\mathrm{R}^{2}$ : 0.06265

Chi squared: 64.22

Degrees of freedom: 34.0

$\mathrm{P}$-value $=0.117$ with degrees of freedom $=8$

Overall Model Significance: 0.00

With a 50-50 classification system, almost 84 percent of the individuals in the sample were correctly classified as those who place high degree of importance on bed and breakfast events when participating in the agritourism activities. 
The logit model summary for participation in bed and breakfast events is displayed in table 3. Among the 34 independent variables, WIDERFRUITS, AGRITOURMKT, FACILITYIMP, UNDER17, RETIRED and INC60K-79K variables are positively influencing, whereas, AGRITOURPAPER, MALE, 2YEARCOLLGE, HOMEMAKER and INC20K-39K are negatively impacting, at least at a $10 \%$ level on bed and breakfast events when participating in the agritourism activities. The model results indicate that, among the respondents, those who consumed a wider variety of fruits in the past 5 years (WIDERFRUITS) are 5\% more to be willing to participate in the bed and breakfast agritourism activity because of concerns about fresh fruits and vegetables compared to those who thought otherwise.

Table 3. Logit regression results

\begin{tabular}{rlr|r|r|r|c}
\hline S.No & \multicolumn{1}{|c|}{ Variable } & Coefficient & $\begin{array}{c}\text { Standard } \\
\text { Error }\end{array}$ & T-Ratio & Probability & $\begin{array}{c}\text { Marginal } \\
\text { effect }\end{array}$ \\
\hline & Constant & $-0.182^{* * *}$ & 0.023 & -8.057 & 0.000 & -0.1817 \\
1. & MOREFRUITS & -0.00017 & 0.00011 & -1.512 & 0.131 & -0.0002 \\
2. & WIDERFRUITS & $0.055^{* * *}$ & 0.011 & 5.146 & 0.000 & 0.0555 \\
3. & PYOVISITS & -0.0004 & 0.0003 & -1.211 & 0.226 & -0.0001 \\
4. & PYOEXP & 0.0001 & 0.0001 & 1.566 & 0.118 & 0.0001 \\
5. & AGRITOURVISITS & 0.0001 & 0.0001 & 0.614 & 0.539 & 0.0000 \\
6. & DMBILLBOARDADV & -0.018 & 0.012 & -1.58 & 0.114 & -0.0182 \\
7. & DMATMARKETADV & 0.018 & 0.012 & 1.578 & 0.115 & 0.0182 \\
8. & WTPDIRECTMKT & -0.0001 & 0.0001 & -0.047 & 0.963 & 0.0000 \\
9. & WTBGM & -0.0001 & 0.0001 & -0.024 & 0.981 & 0.0000 \\
10. & AGRITOURMKT & $0.022^{*}$ & 0.012 & 1.795 & 0.073 & 0.0217 \\
11. & AGRITOURPAPER & $-0.021^{*}$ & 0.013 & -1.799 & 0.074 & -0.0217 \\
12. & FACILITYIMP & $0.0002^{*}$ & 0.0001 & 1.687 & 0.092 & 0.0002 \\
13. & EDUCATIONIMP & 0.0001 & 0.0001 & -1.501 & 0.134 & -0.0001 \\
14. & GARDEN & -0.0001 & 0.0001 & -0.914 & 0.361 & -0.0001 \\
15. & URBAN & -0.001 & 0.001 & -0.521 & 0.603 & -0.0005 \\
16. & HOUSEHOLD & 0.0001 & 0.001 & 0.352 & 0.725 & 0.0004 \\
17. & UNDER17 & $0.0006 * *$ & 0.0003 & -2.051 & 0.040 & -0.0002 \\
\hline
\end{tabular}




\begin{tabular}{l|l|r|r|r|r|c}
\hline S.No & Variable & Coefficient & $\begin{array}{c}\text { Standard } \\
\text { Error }\end{array}$ & T-Ratio & Probability & $\begin{array}{c}\text { Marginal } \\
\text { effect }\end{array}$ \\
\hline 18. & MALE & $-0.0001^{*}$ & 0.0001 & -1.795 & 0.073 & -0.0001 \\
19. & AGE<20 & -0.003 & 0.025 & -0.127 & 0.899 & -0.0032 \\
20. & AGE21TO35 & 0.003 & 0.016 & 0.206 & 0.837 & 0.0032 \\
21. & AGE36TO50 & 0.0001 & 0.016 & 0.000 & 0.999 & 0.0001 \\
22. & 2YEARCOLLGE & $-0.022^{*}$ & 0.013 & -1.678 & 0.093 & -0.0223 \\
23. & 4YEARCOLLEGE & 0.007 & 0.011 & 0.647 & 0.518 & 0.0073 \\
24. & GRADUATE & 0.015 & 0.013 & 1.178 & 0.239 & 0.0154 \\
25. & RETIRED & $0.034^{*}$ & 0.018 & 1.876 & 0.061 & 0.0336 \\
26. & EMPLOYED & 0.003 & 0.012 & 0.28 & 0.780 & 0.0034 \\
27. & HOMEMAKER & $-0.032^{*}$ & 0.019 & -1.666 & 0.096 & -0.0316 \\
28. & STUDENT & -0.005 & 0.023 & -0.237 & 0.812 & -0.0054 \\
29. & CAUCASIAN & 0.0001 & 0.0001 & 0.251 & 0.802 & 0.0000 \\
30. & INC20K-39K & $-0.039 * *$ & 0.019 & -2.082 & 0.037 & -0.0394 \\
31. & INC40K-59K & -0.011 & 0.014 & -0.767 & 0.443 & -0.0111 \\
32. & INC60K-79K & $0.025^{*}$ & 0.015 & 1.662 & 0.096 & 0.0248 \\
33. & INC80K-99K & 0.016 & 0.017 & 0.98 & 0.327 & 0.0163 \\
34. & INCABOVE100K & 0.009 & 0.014 & 0.642 & 0.521 & 0.0093 \\
\hline
\end{tabular}

$* * *$ Significant at $1 \%$;**Significant at $5 \%$; Significant at $10 \%$.

In terms of agritourism information, those who learned about agritourism from signs at farm markets (AGRITOURMKT) were $2.2 \%$ more likely to be willing to participate in bed and breakfast agritourism activity, whereas those who learned about agritourism from newspapers (AGRITOURPAPER) were $2 \%$ less likely to be willing to participate in the bed and breakfast agritourism activity. A conflicting result were observed among those who learn about agritourism events through newspapers positively contributed towards the likelihood of participation in farm wine tasting events but were unwilling to participate in a bed and breakfast agritourism activity (Govindasamy and Kelley, 2014).

In the case of onsite facility, those who thought that the facility at an agritourism site important (FACILITYIMP) were $0.02 \%$ more likely to be willing to participate in a bed and breakfast agritourism activity. However, the 
AGRITOURPAPER and FACILITYIMP variable is significant at 90\% level but the impact on dependent variables was not statistically significant. Furthermore, respondents who had children under the age of 17 (UNDER17) were $0.02 \%$ more likely to be willing to participate in the bed and breakfast agritourism activity because this may be a new experiences for children who have had little exposure to farm life, growing up in a midsize city. Gender also play a vital role in participation in a bed and breakfast agritourism activity, $0.1 \% \%$ of males (MALE) were less likely to be willing to participate in this event. However, results showed that males were more willing to make more trips to agritourism spots than females (Carpio et al., 2008). This clearly indicates that male were more willing to participate other agritourism events than in a bed and breakfast.

Among respondents, those who have a two year collage education (2YEARCOLLGE) are $2 \%$ less likely to be willing to participate in the bed and breakfast agritourism compared to those who have up to a graduate level and above. A similar result was found in agritourism wine testing event (Govindasamy and Kelley, 2014). Also those who are retired (RETIRED) are 3\% more likely to be willing to participate in a bed and breakfast agritourism activity due to availability of time compared others. Another interesting finding was that homemakers (HOMEMAKER) were less likely to be willingness to participate in the bed and breakfast agritourism activity. A similar result was also found in agritourism wine testing event (Govindasamy and Kelley, 2014). Those who had an income range from 20,000 to 39,000 (INC20K-39K) were $3 \%$ less likely to be willing to participate in the bed and breakfast agritourism activity, whereas those who had an income ranging from 60,000 to 79,000 (INC60K-79K) were $2 \%$ more likely to be willing to participate in the bed and breakfast agritourism activity, because of concerns about the affordability of the event.

\section{CONCLUSION}

Survey results demonstrate that agritourism outlets across the mid-Atlantic region generally appeal to consumers, with a few areas needing improvement. Research and data provided by this study may bring about a useful understanding of consumers' perceptions, behaviors, and actions concerning their purchases, decision

to visit, and general preferences towards bed and breakfast and agritourism activity. It may also generate conversation on how to advance businesses in order to benefit consumers and owners alike in the mid-Atlantic region of the United States, and perhaps may extend to similar nearby farming states outside of the region studied.

\section{ACKNOWLEDGEMENTS}

This study was supported by The Federal-State Marketing Improvement Program (FSMIP), Agricultural Marketing Service, USDA, Grant Number \# 12-25G-0894. 


\section{REFERENCES}

Barbieri, C. 2013. Assessing the sustainability of Agritourism in the US: a comparison between agritourism and other farm entrepreneurial ventures. Journal of Sustainable Tourism, 21 (2):252-270

Browne, William. P. 2001. The failure of national rural policy. Washington, DC: Georgetown University Press

Carpio, E. C., M. K. Wohlgnenant and Boonsaeng, T. 2008. The demand for agritourism in the United States. Journal of Agricultural and Resource Economics, Western Agricultural Economics Association, 33(2): 254-269

Che, D., Veeck, A. and Veeck, G. 2005. Sustaining production and strengthening the agritourism product: linkages among Michigan agritourism destinations. Agriculture and Human Values, 22: 225-234

Chiu, Hoi. Yan., Chan, Chung-Shing and Lawal, M. M. 2016. Local perception and preferences in nature tourism in Hong Kong). Tourism Management Perspectives, 20:87-97

DeFries, G. Asner. and Houghton, R. (Eds). 2004. Ecosystems and land use change. American Geophysical Union, Geophysical Monograph Series -153, Washington, DC

Edgell, David. L.1990. The challenges for tourism education for the future. Journal of Travel Research, 29 (2): 51-52. Doi: 10.1177/004728759002900210

Foley, Jonathan., A, R. DeFries., G. P. Asner, C., Barford, G., Bonan, S. R., Carpenter, F. S., Chapin, M. T., Coe, G. C., Daily, H. K., Gibbs, J. H., Helkowski, T., Holloway, E. A. ,Howard, C. J., Kucharik, C. M., Jonathan, A., Patz, I. C., Prentice, NRamankutty. and Snyder, P. K. 2005 Global consequences of land use, Science, 309: 507; DOI: 10.1126/science.1111772

Govindasamy, R. and Kelley, K. 2014. Agritourism consumers' Participation in wine tasting events: an econometric analysis. International Journal of Wine Business Research, 26 (2): 120 - 138. DOI : http://dx.doi.org/10.1108/IJWBR-04-2013-0011

Ceballos, L. H.1995. Tourism, ecotourism, and protected areas: The state of nature-based tourism around the world and guidelines for its development. IUCN, Cambridge, $U K$

Harvey. 2001.Heritage pasts and heritage presents: Temporality, meaning and the scope of heritage studies. International Journal of Heritage Studies, 7 (4): 319-338

Koutsouris, A., Gidarakou, I., Grava, F. and Michailidis, A. 2014. The phantom of agritourism and agriculture symbiosis? A Greek case study. Tourism management Perspectives, 12:94-103

Kumar, R., Stauvermann, R. and Peter, J. 2016. The linear and non-linear relationship between of tourism demand and output per worker: A study of Sri Lanka. Tourism Management Perspectives, 19: 109-120

Lipton, M. 2005. The family farm in a globalizing world: The role of crop science in alleviating poverty. 2020, Discussion Paper No. 40.Washington, D.C.: International Food Policy Research Institute

McGehee, N. and Kim, K. 2004. Motivation for agritourism entrepreneurship. Journal of Travel Research, 43 (2): 161-170 
National Survey on Recreation and the Environment, (NSRE) :( 2000-2002),The interagency national survey consortium, coordinated by the USDA forest service, recreation, wilderness, and demographic trends research group, Athens, GA and Human Dimensions, Research Laboratory, University of Tennessee, Knoxville, TN

Nickerson, N. P., Black, R. J. and McCool, S. F. 2001. Agritourism: motivations behind farm/ranch business diversification [Electronic version]. Journal of Travel Research 40 (1): $19-26$

Onyango, B., Govindasamy, R., Alsup-Egbers. and Clydette, M. 2015. Uncovering Success Attributes for Direct Farmers' Markets and Agri-Tourism in the Mid-Atlantic Region of the United States. International Food and Agribusiness Management Review, 18(2): 63-78

Schilling, J. B., Witsanu, A. and Yanhong, J. 2014. Does agritourism enhance farm profitability? Journal of Agricultural and Resource Economics, 39(1): 69-87, ISSN 1068-5502

Surendran, A. and Sekar, C. 2010. An economic analysis of willingness to pay (WTP) for conserving the biodiversity", International Journal of Social Economics, 37 (8):637-648

Surendran, A. and Sekhar. C. 2011. A comparative analysis on the socio-economic welfare of dependents of the Anamalai Tiger Reserve (ATR) in India. Margin: The Journal of Applied Economic Research 5 (3): 361-379

Susan, Ryan., Kristy, DeBordand Kristin, M. 2006. Agritourism in Pennsylvania: an industry assessment report, the center for rural Pennsylvania

Sutherland, Lee-Ann., Toma, Luiza., Barnes, P. Andrew., Matthews, B. K. and Hopkins, J. 2016. Agri-environmental diversification: Linking environmental, forestry and renewable energy engagement on Scottish farms, Journal of Rural Studies, 47: 10-20

Tew, C. and Barbieria, C. 2012. The Perceived benefits of agritourism: the provider's perspective. Tourism Management, 33 (1): 215-224

U. S. Department of Agriculture, National Agricultural Statistics Service. 2012. The Censuses of Agriculture, 2011. http://www.agcensus.usda.gov/index.asp

U. S. Department of Agriculture, National Agricultural Statistics Service. 2010. The Censuses of Agriculture, 2009. http://www.agcensus.usda.gov/index.asp

University of California Small Farm program. 2012. What is Agritourism?, University of California Cooperative Extension, UC small farm program, Division of Agriculture and Natural Resources, University of California

Wilson, J., Thilmany, D. and Sullins, M. 2006. Agritourism: A potential economic driver in the rural west. Economic development report. Cooperative extension. Colorado State University. Department of Agricultural and Resource Economics. February 2006

WTO. 2004. Tourism Market Trends 2003 Edition: World overview and tourism topics. Madrid: WTO 